\title{
ÉPÍTÉSZETI KONCEPCIÓK
}

\section{ARCHITECTURAL CONCEPTS}

\author{
Cserényi-Vörös Erika ${ }^{1}$, Borsos Ágnes ${ }^{2}$, Gyergyák János ${ }^{3}$ \\ ${ }^{1}$ Szent István Egyetem, Ybl Miklós Épitéstudományi Kar, 1146, Magyarország, Bu- \\ dapest, Thököly út, 74; +36-20-4956465, erikavorosg@gmail.com \\ ${ }^{2}$ Pécsi Tudományegyetem, Müszaki és Informatikai Kar, agnesboros@gmail.com \\ ${ }^{3}$ Pécsi Tudományegyetem, Müszaki és Informatikai Kar,gyergyakjanos@gmail.com
}

\begin{abstract}
The most exciting part of the architectural design is the process of making concept, based on multiple investigations. One does not need only a good working knowledge of the profession, but also has to be pretty sensitive and responsible, too. The conscious and reflective decision-making process should result in an established, functioning concept. The art and science of concept making process is irrespective of scale. During concept development, the same aspects and dimensions are involved, independently of the 'product'.
\end{abstract}

Keywords: architecture, concept, urban, design, sustainable

\section{Összefoglalás}

Az építészeti alkotás, tervezés egyik legizgalmasabb része a koncepcióalkotás folyamata, amely a témának megfelelő mélységü, érzékenységü, sokrétü vizsgálati anyagra támaszkodva fogalmazódik meg. A tudatos, felelősségteljes és kellő mértékben szenzitív tervezői döntéssorozat eredménye lehet egy megalapozott, társadalmi és szakmai szempontból is helytálló koncepció kialakítása. Egy-egy termék koncepciójának a megalkotásánál hasonló síkokat, dimenziókat kell végigjárni, érinteni, értelmezni.

Kulcsszavak: épitészet, koncepció, városépitészet, dizájn, fenntarthatóság

\section{Koncepcióalkotás folyamata}

A kreatív alkotómunka alapja a koncepció megalkotása. Ez egy olyan több lépcsőfokból álló folyamat melynek van egy általános "felfelé", előrehaladó iránya, de megteremti a visszalépés, előreugrás, azaz az újragondolás lehetőségét is. A koncepcióalkotás folyamata lehet egy lineárisan felépülő alkotó munka, de összetettségéből, komplexitásából adódóan inkább jellemző az önmagába, egyes lépcsőfokokhoz visszaforduló rendszer. Ebből következően egy sokkal lazább, megengedőbb alkotó, vizsgálódó rendszerről beszélünk, ahol a sokváltozós bementi adatok és a szempontrendszer változása miatt, más-más eredmények, megállapítások születhetnek, vagy válhatnak relevánssá egyazon alkotás koncepcionálásában. A koncepciótermék lényegét tekintve az alkotó munka egy procedurális folyamat, melyre utólag visszatekintve már egyértelmü állomásokat és döntéseket látunk. Azonban az egyértelmüség, egyszerüség nem egyenlő a primer gondola- 
tokkal, ötletekkel, azért érezzük ezeket lényeginek, mert egy hosszú, sokszor, sokféleképpen körbejárt problémára, felvetésre ad esszenciális választ.

\subsection{Koncepcióalkotás elemei}

Összességében a koncepcióalkotás 3 fö részből tevődik össze:

- kutatás, elemzés: program megfogalmazása, problémák meghatározása, releváns vizsgálatok, megismerés, beleélés, helyzet értelmezése;

- mérlegelés: értékelemzés, szemléletmód, érzékenység, általános célok meghatározása, alapgondolatok megfogalmazása;

- döntés: koncepcióelemek meghatározása, célok részletezése, formakoncepciók.

\section{Városi otthon koncepció Charlott, USA}

A koncepcióalkotás művelete, alapvető lépcsőfokai, a gondolkodás menete, a tervezöi szemléletmód, egy sokváltozós folyamat. A lényeg a gondolkodásmenet azaz a koncepcióalkotási metodika.

Ezen gondolatmenet alapján fogalmaztuk meg Borsos Ágnes és Gyergyák János kollégámmal az Urban Design Home pályázatra készített koncepció projekt is, amely a városi funkciók (lakó, kereskedelem, szolgáltatás, park, piac, parkolás) egy tervezési területen történő szeparált, de mégis egységet alkotó elhelyezéséről szól. Egy kisváros megfogalmazása, lényege, egyetlen telken.

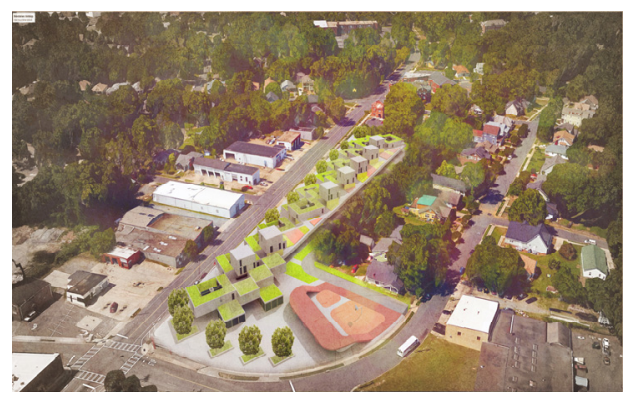

1. ábra. Végleges koncepciótelepités

\subsection{Kutatás, elemzés}

A kutatás, elemzés lényege a koncepcióalkotás bázisának megteremtése. Minél szélesebb körben vizsgálódunk (az ésszerü relevancia határain belül), annál szélesebb és biztosabb alapot képezhetünk a koncepcióalkotás folyamatának, lépcsőinek.

A pályázat részletes programkiírása karakteresen meghatározza az elvárt kompetenciákat a funkciók elhelyezkedését, méretét és egymáshoz való viszonyát tekintve. Lényeges szempont az akadálymenetesítés megvalósítása és a fenntartható, energiatudatos építészet aspektusai. A programkiírás bemutatja a legfontosabb tényezöt is, azaz a lakások használóit. Ezen túlmenően a kutatás fontos eleme a tervezési területet felfogása, analizálása, müködési rendszerének megértése.

\section{Összességben elmondható:}

- a telket egy abszolút heterogén épített környezet határolja mind építészeti, mind funkcionális szempontból;

- a területen az elvárt funkciókat és a hozzájuk rendelt területeket tekintve a a telekméret szükös;

- a kis területen elhelyezendő sokféle funkció komoly lakossági és müködésbeli súrlódásokhoz, fennakadásokhoz vezethet.

- fenntartható építészeti aspektusok.

\subsection{Mérlegelés}

A mérlegelés a koncepcióalkotás egyik legfontosabb lépcsöje, hiszen ebben a fázisban döntjük el, hogy mi az amire a tervünknek reagálnia kell, milyen kérdésekre, milyen szintü válaszokat fogalmaz meg. Már ebben a fejezetben komoly hatással van maga az alkotó a termékre, hiszen saját szemléletmódja, érzékenysége, értékrendje jelentős befolyással bír a releváns kérdésekre is. Ezek a meghatározások lesznek a koncepció kiinduló alapelemei, melyekre folyamatosan támaszkodhatunk.

A Charlott-ba készülő pályázatot tekintve a legfontosabb gondolat az élhető "vá- 
ros" megteremtése az adott területecskén. $\mathrm{Az}$ élhetőség mint meghatározás túl általános megfogalmazás, így szükséges annak konkrétabb építészeti, városépítészeti, társadalmi, fenntarthatósági megfogalmazása.

Koncepció alapgondolatai:

- egységes építészeti, tájépítészeti rendszer kialakítása, mely rendezőerővel bír közvetlen és tágabb heterogén környezetében;

- túlépítettség elkerülése: mértéktartó építészeti léptékek;

- lakó és szolgáltató funkciók horizontális és vertikális szeparálása;

- variábilis közösségi terek kialakítása (szeparálás finomító eszköze);

- lakófunkciók intimitásának biztosítása;

- szolgáltató funkciók jó megközelíthetősége

- a fenntartható építészet formai megjelenése ne csak épület applikációkban fogalmazódjon meg;

\subsection{Döntés: koncepció alapjainak konkrét hatásai}

A koncepcióalkotás folyamatának utolsó lépfoka a döntéshozatal által meghatározott relevanciák konkrét hatása a tervre. Ebben a fejezetben ölt tényleges formát, vagy inkább folyamatosan formálódik a mü maga, az előzőleg bejárt lépcsőfokok alapján. Minél magasabbra jutunk, minél többször járjuk be ezt a lépcsőt más- más "cipővel" annál egyértelmübb és tisztább koncepciót tudunk felvázolni.

A pályázati projekt tekintetében a koncepció megvalósulását funkciókra szedve a legalakamasabb bemutatni.

Differenciált közösségi terek:

- közösségi tér: mindenki számára;

- szeparált közösségi tér: csak a lakók számára;

- magánkert: lakásokhoz tartozó privát terület;
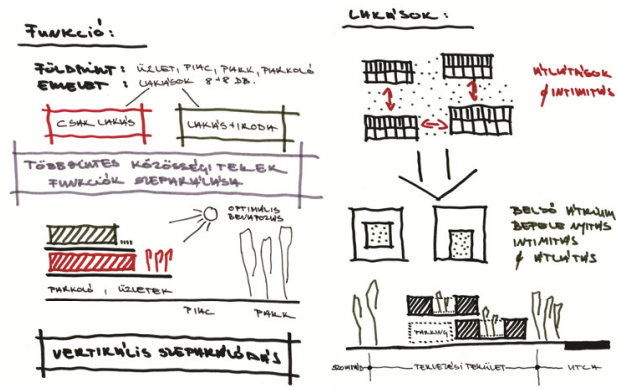

2. ábra. Koncepció alapelemei

Közösségi, szolgáltató funkciók:

-horizontális szeparálás: terület északkeleti része a legfrekventáltabb terület;

- vertikális szeparálás: földszinti elhelyezkedés a megközelíthetőség miatt;

- sokféle funkció: variábilis terek;

- közterek sokféle használatának indukálása: többfunkciós közösségi terek;

- parkolók kialakítása a lakásokhoz közel: emelt szint, plató alatt az északi oldalon;

Lakó funkciók:

- horizontális szeparálás: terület dél-nyugati része kevésbé terhelt;

- vertikális szeparálás: főként emelet szinteken;

- lakások intimitása: befelé forduló funkció: átrium házak;

- lakások egymásra halmozása eltolva: helygazdaságosság, jó benapozás;

Fenntarthatóság:

- maximális benapozás: átrium lakások lépcsőzetes egymásra helyezése;

- funkciók tájolása benapozásnak megfelelően;

- passzív napenergia használat: átriumok nyitása, zárása, belső fás kert;

- természetes árnyékolás;

- aktív napenergia használat: napkollektor, napelem; 


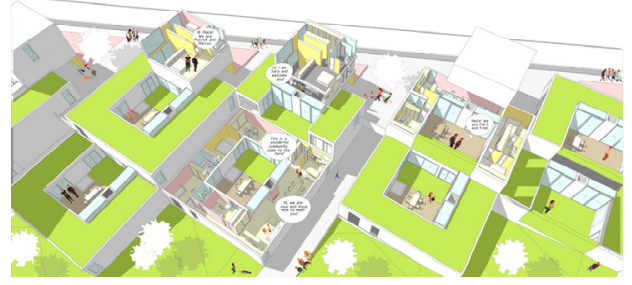

3. ábra. Lakások lépcsözetes elhelyezkedése

\section{Következtetések}

Összességében kijelenthető, hogy a használó számára is jól müködő koncepció kialakításához a tervező részéről kellő elhivatottság, szakmai tudás, társadalmi érzékenység és felelös gondolkodás szükséges. Az adott helyzet kellö mélységü értelmezése, a következtetések levonása és a koncepció alapjainak meghatározása az "ajánlott" lépcsőfokok bejárásán túl, nagyban függ az alkotó személyétöl, értékrendjétől. A sokváltozós rendszerből és a személyesség bevonódásából adódóan egy előre pontosan nem determinálható eredményű folyamatról beszélünk. Ebből fakadóan a folyamatok viszonylag pontos meghatározásával sem lehet egyértelmü eredményeket megjósolni, hiszen a bonyolult rendszert mindig az adott egyén használja sajátos szemléletmódjának megfelelően. Az egyén folyamatos jelenléte teszi egyedivé az alkotást. A koncepcióalkotás lépéseinek meghatározása csak irányt mutat a felhasználónak a lépcsőfokok alkalmazásához. Az, hogy egy adott koncep- ció kialakításhoz ezt a lépcsőt, hányszor és milyen magasságig, mélységi járja be, az már személyes aspektus, egyéni szemléletmód.

\section{Szakirodalmi hivatkozások}

[1] Ian Bentley.; Alan Alcock.; Paul Murrain.; Sue McGlynn.; Graham Smizh: Responsive enveronment: a manual for designers. The Architectural Press Ltd, London, 1985

[2] BIG A/S: Yess is more. Taschen, Coppenhagen, 2009

[3] Edward de Bono: Laterális gondolkodás. HVG kiadó, Budapest, 2015

[4] Dominic Bradbury: Korszerü természetes ház. Terc kiadó, Budapest, 2011

[5] Lukovich Tamás: Fenntartható fejlesztés. Terc kiadó, Budapest, 2013

[6] Lukovich Tamás: Lenyügözö labirintus. Terc kiadó, Budapest, 2016

[7] Moravánszky Ákos.; M. György Katalin: Technika és természet. Terc kiadó, Budapest, 2013

[8] Antony Radford.; Selen Morkoc.; Amit Srivastava: A modern épitészet elemei. Terc kiadó, Budapest, 2016

[9] Tim Richardson: Conceptuális kertek. Terc kiadó, Budapest, 2008

Kutatást támogatta:

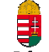

Funeu Fưromersom AZ EMBERI ERŐFORRÁSOK MINISZTÉRIUMA ÚJ NEMZETI KivÁLÓSÁg ProgramJÁNAK TÁMOGATÁSÁVAL KÉSZÜLT

SUPPORTED THROUGH THE NEW NATIONAL EXCELLENCE PROGRAM OF THE MINISTRY OF HUMAN CAPACITIES 